\title{
Reconstruction of seagrass dynamics: age determinations and associated tools for the seagrass ecologist
}

\author{
Carlos M. Duarte ${ }^{1}$, Nuria Marbá ${ }^{1}$, Nona Agawin ${ }^{2}$, Just Cebrián ${ }^{1}$, Susana Enríquez ${ }^{1}$, \\ Miguel D. Fortes ${ }^{2}$, Margarita E. Gallegos ${ }^{3}$, Martín Merino ${ }^{4}$, Birgit Olesen $^{5}$, \\ Kaj Sand-Jensen ${ }^{5}$, Janet Uri ${ }^{2}$, Jan Vermaat ${ }^{6}$ \\ ${ }^{1}$ Centro de Estudios Avanzados de Blanes, CSIC, Camí de Santa Bárbara s/n, E-17300 Blanes, Girona, Spain \\ ${ }^{2}$ Marine Science Institute, C5, University of The Philippines, Diliman, Quezon City, Philippines \\ ${ }^{3}$ Departamento de Hidrobiología, Universidad Autónoma Metropolitana - Iztapalapa, Michoacán y Purísima, col. Vicentina, \\ AP 55-535, 09340 México D.F., Mexico \\ ${ }^{4}$ Instituto de Ciencias del Mar y Limnología, Universidad Nacional Autónoma de México, 04510 México D.F., Mexico \\ ${ }^{5}$ Freshwater Biological Laboratory, University of Copenhagen, 51 Helsingersgade, DK-3400 Hillerød, Denmark \\ ${ }^{6}$ International Institute of Infrastructure, Hydraulic \& Environmental Engineering, Oude Delft, PO Box 3015, 2601 DA Delft, \\ The Netherlands
}

\begin{abstract}
All seagrasses are rhizomatous plants that grow by reiteration of a limited set of modules. Their past growth history can therefore be reconstructed from the scars left by abscised leaves and flowers on the long-lived rhizomes or the seasonal signals imprinted in the frequency and size of their modules. We provide here the basic foundations and assumptions of these reconstruction techniques and the calculations involved in their application. We then show their reliability and potential to quantify an array of ecological processes, such as plant demography, leaf and rhizome production, flowering intensity, and seagrass responses to anthropogenic perturbations, based on our recent studies of Mediterranean, Caribbean and Indo-Pacific seagrass species. Reconstruction techniques have also proven useful in demonstrating the role of seagrasses as tracers of sediment movement over seagrass beds and the rates of colonisation and expansion of seagrass patches. These reconstruction techniques should provide a powerful tool to improve our knowledge of seagrass species and populations from remote areas based on a single or just a few visits. This should, therefore, allow us to sample many seagrass meadows using limited resources, thus generating a strong foundation for the study of comparative seagrass ecology and testing of theories previously applied to terrestrial plant populations.
\end{abstract}

KEY WORDS: Seagrasses · Age determinations · Growth · Demography · Dynamics

\section{INTRODUCTION}

Realisation of the key role of seagrasses in coastal ecosystems has fostered ever-growing efforts to quantify their annual productivity and growth dynamics. The geographic distribution of this effort has been, however, concentrated in regions in the USA, Caribbean Basin and Bahamas, western Europe, Aus- tralia and the western Mediterranean, with only a few studies focused on seagrasses elsewhere. This patchy distribution of research effort is largely attributable to the need for repeated sampling to determine seagrass growth, which is the main constraint to extending our knowledge to regions away from research laboratories. A better geographical balance of our knowledge of seagrass ecology is needed to ensure that this knowl- 
edge refers to the general case, rather than the exceptions, and to allow reliable calculations of the role of seagrasses in the dynamics of the global and coastal ocean. Hence, our knowledge of seagrass ecology and their responses to perturbations would become more general and relevant if techniques were available that allowed the quantification of seagrass growth dynamics from one or a few visits (Gallegos et al. 1993). These techniques are available, but their full potential has yet to be developed.

Petersen (1913) was the first to use the sequence of rhizome internodal lengths of the seagrass Zostera marina to calculate productivity in Danish waters. Over half a century later, Patriquin (1973) outlined the basic ideas and demonstrated how measurements based on age determinations could help to study the growth of Thalassia testudinum. These techniques have as a common basis the ability to determine the age of seagrass rhizomes (e.g. Petersen 1913, Patriquin 1973, Duarte \& Sand-Jensen 1990a, b, Gallegos et al. 1993). Techniques based on age determinations have been used since, alone or in combination with standard marking techniques, to reconstruct different aspects of seagrass ecology (Table 1). Yet, these techniques have been applied only to a limited number of genera (Table 1), leading to the misconception that they are species-specific. As a consequence, their applicability to a wider set of seagrass species remains untested and their potential unexplored. Techniques based on age determinations can be applied, however, to study the growth of most seagrass flora, and the generality of these techniques is best suggested by the fact that essentially the same techniques have been used to study growth and demography of a range of plants (e.g. Sarukán 1978, Duke \& Pinzón 1992).

Our goal here is to formalise the use of techniques based on age determinations as powerful tools to reconstruct seagrass dynamics from a single or a few sampling event(s), and therefore encourage their use to expand the geographic spread of our knowledge of seagrass ecology. We do this by describing the basic foundations and assumptions of the methods and the calculations involved in their application. We then describe the applicability of the methods to different seagrass species, using data from Mediterranean, Caribbean and Indo-Pacific species.

\section{TECHNIQUES BASED ON AGE DETERMINATIONS AND PLASTOCHRONE INTERVALS}

\section{The foundation of reconstruction methods}

The set of reconstruction techniques described here take advantage of the simple architecture of seagrasses described by den Hartog (1970) and more explicitly by Tomlinson (1974). Seagrasses are rhizomatous plants that grow by reiteration of a limited set of modules (Fig. 1). These are (1) rhizome internodes, which ensure the vegetative spread of the organism and may be horizontal (also referred to as long shoots) or erect (also referred to as short or vertical shoots), depending on whether they spread the plant sidewards or upwards; (2) leaves, where photo-

Table 1. A compilation of the use of techniques based on age determinations to examine different aspects of seagrass ecology

\begin{tabular}{|lll|}
\hline Aspect studied & Species & Source \\
\hline Shoot demography & Cymodocea nodosa & Duarte \& Sand-Jensen (1990a, b), Perez et al. (1994) \\
& $\begin{array}{l}\text { Halodule wrightii } \\
\text { Syringodium filiforme }\end{array}$ & Gallegos et al. (1994) \\
& Gallegos et al. (1994) \\
Leaf production & Zostera marina & Gallegos et al. (1993) \\
& Cymodocea nodosa & Duarte \& Sand-Jensen (1990a, b) \\
& Posidonia oceanica & Pergent \& Pergent-Martini (1990) \\
& Halodule wrightii & Gallegos et al. (1994) \\
& Syringodium filiforme & Gallegos et al. (1994) \\
& Thalassia testudinum & Patriquin (1973), Gallegos et al. (1993) \\
Rhizome growth & Cymodocea nodosa & Perez (1989), Duarte \& Sand-Jensen (1990a, b), Terrados \& Ros (1992) \\
& Posidonia oceanica & Pergent \& Pergent-Martini (1990) \\
& Halodule wrightii & Gallegos et al. (1994) \\
& Syringodium filiforme & Gallegos et al. (1994) \\
& Thalassia testudinum & Patriquin (1973, 1975), Gallegos et al. (1993) \\
Flowering intensity & Cymodocea nodosa & Gallegos (unpubl.) \\
& Posidonia oceanica & Pergent \& Pergent-Martini (1990) \\
& Thalassia testudinum & Durako \& Moffler (1987), Cox \& Tomlinson (1988), Gallegos et al. (1992) \\
Colonization rate & Cymodocea nodosa & Duarte \& Sand-Jensen (1990a, b) \\
\hline
\end{tabular}


synthesis and nutrient uptake from the water column occur, and which arise from growing meristems at the rhizome apices; and (3) roots, which serve to anchor the plant and take up sediment nutrients, and appear at regular intervals along the rhizome. The insertion points of the leaves on the rhizome are referred to as nodes and are identifiable by the scars left after leaf abscission (Fig. 1). Accordingly, the rhizome pieces in between 2 consecutive leaf scars are termed rhizome internodes. These are produced in the time interval between the formation of 2 successive leaves, which is termed plastochrone interval (Erikson \& Michelini 1957). This architecture ensures a close (1:1) relationship between the production of rhizome internodes and leaves.

This simple depiction of seagrass growth becomes more complex as the degree of differentiation between vertical and horizontal rhizomes increases (cf. Tomlinson 1974), from species with monomorphic rhizomes (e.g. genera Zostera and Enhalus) to those with differentiated major (long shoots) and minor (short shoots) axes (e.g. genera Thalassia, Thalassodendron and $C y$ modocea; Fig. 2). Increasing differentiation between vertical and horizontal rhizomes is associated with greater differences in the size and rhythm of formation of leaves and rhizome internodes on the 2 axes. Verti-

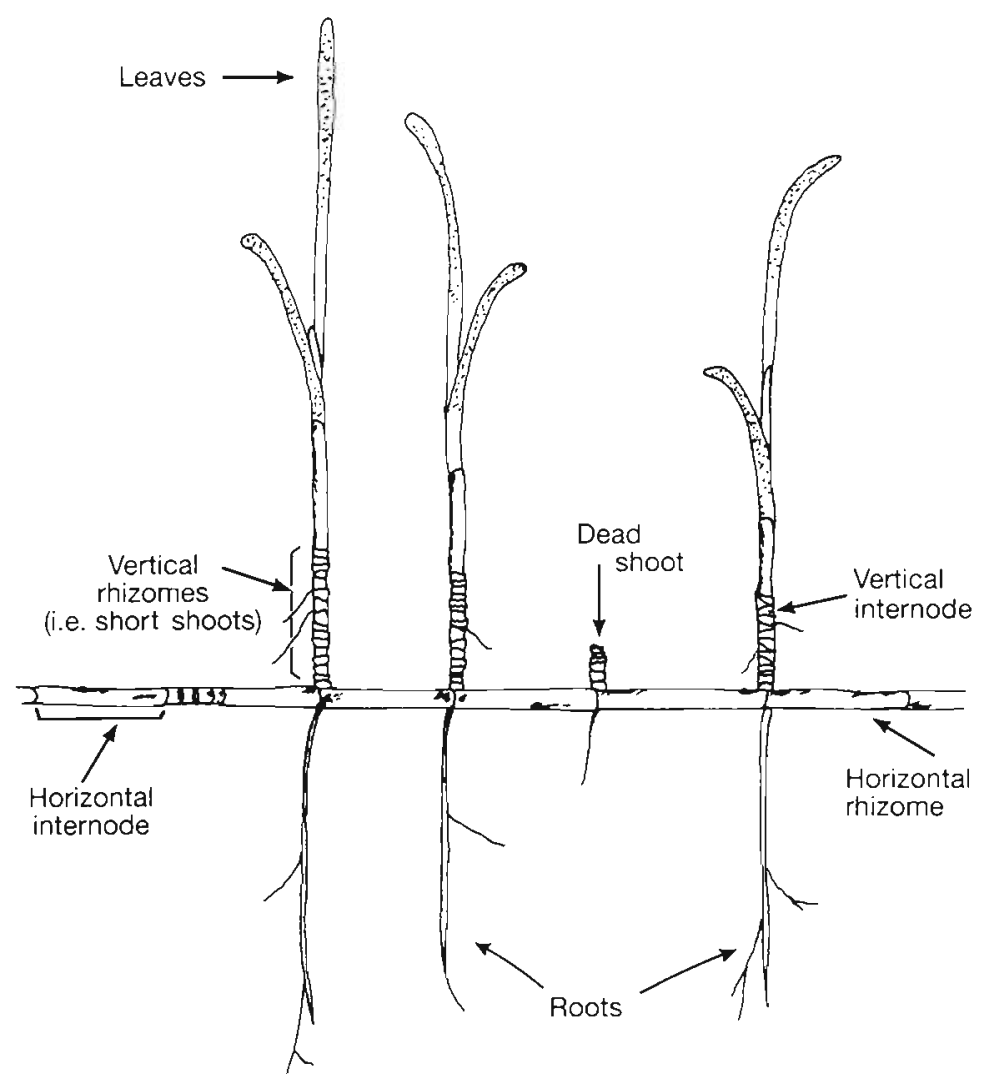

Fig. 1. Modules of a typical seagrass cal rhizomes usually have longer leaves, shorter internodes, and longer plastochrone intervals than horizontal rhizomes (Duarte 1991). The leaves produced by the horizontal meristem of Thalassia sp., which represent an advanced differentiation between horizontal and vertical rhizomes, are reduced to small bracteae (Tomlinson \& Vargo 1966). Lateral branches have also been reported to grow slower and have shorter internodes than primary axes (Brouns 1987). The faster growth rates of primary axes compared to branches, whether lateral or vertical (i.e. shoots), are probably a consequence of the strong apical dominance typical of rhizomatous plants (Bell \& Tomlinson 1980).

The close $(1: 1)$ relationship between the production of rhizome internodes and leaves is the basis for age determinations of seagrass shoots and rhizomes, which can be estimated as the number of leaf scars (or internodes) plus standing leaves produced since the appearance of the shoot or rhizome of interest. The basic time units of the resulting age estimates are plastochrone intervals, which have been proposed to represent the internal growth rhythm of the plants, thereby providing useful estimates of 'biological time' (Erickson \& Michelini 1957, Lamoreaux et al. 1978). Yet, these time units are species-specific (cf. Duarte 1991) and also depend on environmental conditions (e.g. Hillman et al. 1989) and are, therefore, difficult to compare among different species or to integrate into ecosystem models, which require their translation into absolute time (e.g. days) to express rates (cf. Duarte 1991).

\section{Translating plastochrone intervals into absolute time units}

The translation of plastochrone intervals into absolute time assumes linearity between the 2 time units (Erickson \& Michelini 1957, Patriquin 1973). The annual mean duration in days of a plastochrone interval (PI) is to a large extent a species characteristic. This is reflected in the much greater variance between than within species (coefficient of variation $139 \%$ and $17 \%$ respectively; Duarte 1991 ), which depends on environmental conditions (e.g. Hillman et al. 1989). The annual average mean plastochrone intervals for different species range between 1.1 and $47.2 \mathrm{~d} \mathrm{PI}^{-1}$ for vertical rhizome internodes and associated leaves, and between 1.7 and $42.4 \mathrm{~d} \mathrm{PI}^{-1}$ for horizontal rhizome internodes and associated leaves (Duarte 1991). Thus, annual means of species- 


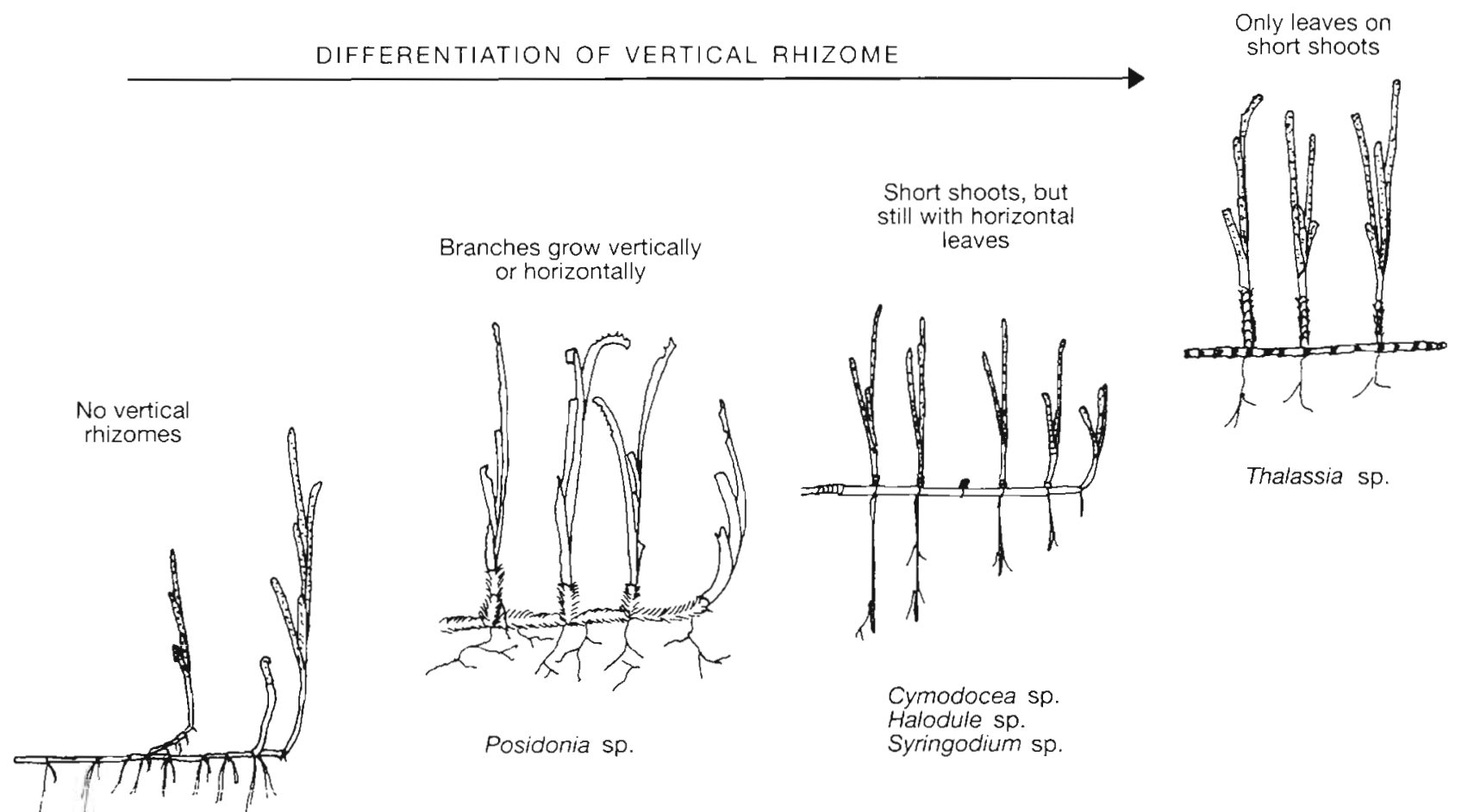

Zostera spp. Enhalus acoroides Heterozostera sp.
Fig. 2. Gradient of increasing differentiation between horizontal and vertical rhizomes in different seagrass genera, from those with no differentiation to those which only have leaves on the vertical rhizomes specific plastochrone intervals may be used as a first approximation to translate PI into absolute time. Yet, there is considerable variability in PI within species, resulting from environmental differences, reflected both in differences among populations and variability at interannual and seasonal time scales within populations. Consequently, reliable estimates of seagrass age should be based on population-specific estimates of PI duration in days

The annual mean PI may be remarkably constant for some species (e.g. 26 to $33 \mathrm{~d}$ for Cymodocea nodosa; Cayé \& Meinesz 1985, Perez 1989, Duarte \& Sand-Jensen 1990a, Terrados \& Ros 1992), and vary substantially among populations of other species (e.g. 28 to $69 \mathrm{~d}$ in Posidonia oceanica; T. Alcoverro unpubl.). Differences in the annual mean PI among populations are likely to derive from differences in the growth conditions they experience. Hence, the rhythm of leaf formation has been shown to depend on light availability (e.g. Hillman et al. 1989), temperature (Barber \& Beherens 1985), nutrient availability (Short 1987, Perez et al. 1991), and sediment dynamics (Gallegos et al. 1993). Interannual differences in leaf PI occur (e.g. Pergent \& Pergent-Martini 1990, Marbá et al. 1994a) associated with interannual differences in growth conditions (light, nutrients, etc.) and perturbations, such as altered sediment dynamics
(Marbá et al. 1994a). Interannual variability in PI is usually much smaller than seasonal variability, such that the linearity between PI and absolute time assumed by these age determinations is best supported at interannual time scales (cf. Brouns 1985a, b). Estimates of seagrass age are, therefore, more accurate for long-lived ( $>1 \mathrm{yr}$ ) than for short-lived seagrass species (cf. Duarte 1991). This explains why techniques based on age determinations have mostly been applied in the past to seagrasses living longer than 1 yr (Table 1).

Seasonal variation in PI is considerable in the temperate zone, where leaf production is reduced during winter (e.g. Sand-Jensen 1975, Perez 1989, Terrados \& Ros 1992). Yet, tropical seagrasses also display some, at times considerable, seasonality in leaf formation rate (Brouns 1985b) which is difficult to attribute to limiting light or temperature. This variability may be triggered instead by intrinsic phenologic events, such as flowering and reproduction, with the associated drainage of resources. The clues for the seasonal pattern of tropical seagrasses may be annual changes in photoperiod, as has been reported for tropical plants on land (Duke \& Pinzón 1992). Indeed, growth minima of Thalassia testudinum in the Mexican Caribbean, where incoming irradiance and water temperature are permanently high (van Tussenbroek 1993), follow flowering (Galle- 
gos et al. 1992, Marbá et al. 1994a). Seasonal variability in PI must be smaller in slow-growing seagrasses, which integrate seasonal variability better in their long PI (Duarte 1991).

\section{Direct measurements of the plastochrone interval}

Direct measurements of the duration of leaf PI $\left(d^{\text {leaf }}{ }^{-1}\right.$ ) are obtained from observations of the emergence of new, unmarked, leaves on marked shoots (Zieman 1974):

$$
P I=\frac{\text { Time interval }(\mathrm{d}) \times \text { No. of marked shoots }}{\text { No. of leaves formed on marked shoots }}
$$

Leaf PI is usually measured over short periods (e.g. 9 to $30 \mathrm{~d}$; e.g. Brouns 1985a), when shoots have produced at most a single leaf. The basic data obtained for each shoot are, therefore, binary $(0$ or 1 new leaf formed), and the estimated PI represents the inverse of the fraction of shoots that formed new leaves over the marking period. Statistical tables indicate that the error around fractions is considerable at small sample sizes (Sokal \& Rohlf 1981). For instance, 100 marked shoots are required to obtain a $95 \%$ confidence limit of $10 \%$ of the mean proportion of shoots that developed new leaves when only half of the shoots did so. Hence, a large number of shoots must be marked to obtain reasonably precise estimates of plastochrone interval duration for measurement periods shorter than the expected plastochrone intervals (Brouns 1985a). Alternatively, more precise PI estimates are obtained when marking periods are extended to have more than 1 leaf produced, on average, on each shoot (Brouns 1985a). This, however, reduces the temporal resolution of the sampling programme and increases the risk of losing marked leaves, thereby underestimating leaf growth.

\section{Reconstruction techniques to estimate plastochrone intervals}

Direct measurements of seagrass plastochrone intervals require repeated sampling and considerable sampling effort, such that researchers using marking techniques often choose to base their estimates of seagrass growth on the observed leaf extension instead of using techniques based on age determinations. The use of techniques based on age determinations, however, is more convenient when the PI is already known. Additionally, PI can be estimated from seasonal signals imprinted in the size of seagrass modules (e.g. Duarte \& Sand-Jensen 1990b, Pergent \& Pergent-Martini 1990, Gallegos et al. 1993), much like the marks used to estimate annual growth of molluscs, fish and trees.
The seasonality of seagrass growth results in annual cycles in the size of leaves, petioles, and rhizome internodes (Duarte \& Sand-Jensen 1990b, Pergent \& Pergent-Martini 1990, Gallegos et al. 1993). Time series of module size allow, therefore, the inference of the number of modules produced annually. The $1: 1$ correspondence between rhizome internodes and leaves implies that knowledge of the number of rhizome internodes produced per year can be easily translated into the number of leaves and the annual mean PI

Because leaf longevity is generally $<1$ yr (Duarte 1991), leaves representing consecutive annual length maxima or minima are not alive on any one shoot. Seasonal cycles in leaf size are, therefore, useless to reconstruct the annual mean PI, and only modules remaining in the plant for more than $1 \mathrm{yr}$, allowing the presence of modules produced during consecutive growth maxima (or minima) at any one time, can be used to infer the annual mean PI. The petioles or sheaths of the leaves of some seagrasses (e.g. Thalassia testudinum, Posidonia oceanica, Enhalus acoroides) remain attached to the shoots long after the leaves are shed. The thickness of $P$. oceanica petioles or sheaths has been shown to exhibit annual cycles (Pergent \& Pergent-Martini 1990). Whether the thickness of standing petioles of other species shows similar annual cycles has, however, not been tested.

Seagrass rhizomes live longer than leaves (Duarte 1991), and some rhizomes live for decades (e.g. Cymodocea nodosa, Duarte \& Sand-Jensen 1990a; Thalassia testudinum, Marbá et al. 1994a). This longevity renders seagrass rhizomes the most appropriate tool to reconstruct the annual mean duration of PI. Moreover, cycles in a variable can only be unambiguously identified in series at least 3 -fold longer than the expected period. Thus, use of the time series of rhizome internodal length to reconstruct the annual mean PI is most precise for seagrasses whose rhizome lives for more than 3 yr.

The use of annual cycles in the length of rhizome internodes found in many seagrass species to estimate PI, and subsequently leaf productivity, was first noted in Zostera marina by Petersen (1913). This strong seasonality was later demonstrated in the Mediterranean species Cymodocea nodosa (Cayé \& Meinesz 1985, Duarte \& Sand-Jensen 1990b), allowing estimates of annual mean PI similar to those obtained using direct measurements (Duarte \& Sand-Jensen 1990b). However, reconstruction of annual mean PI from horizontal rhizomes requires the examination of intact rhizomes pieces produced over more than $1 \mathrm{yr}$. It requires, in the case of Cymodocea nodosa, rhizome pieces more than $1 \mathrm{~m}$ long (Duarte \& Sand-Jensen 1990a, Duarte 1991). Hence, even though horizontal rhizomes are often suf- 


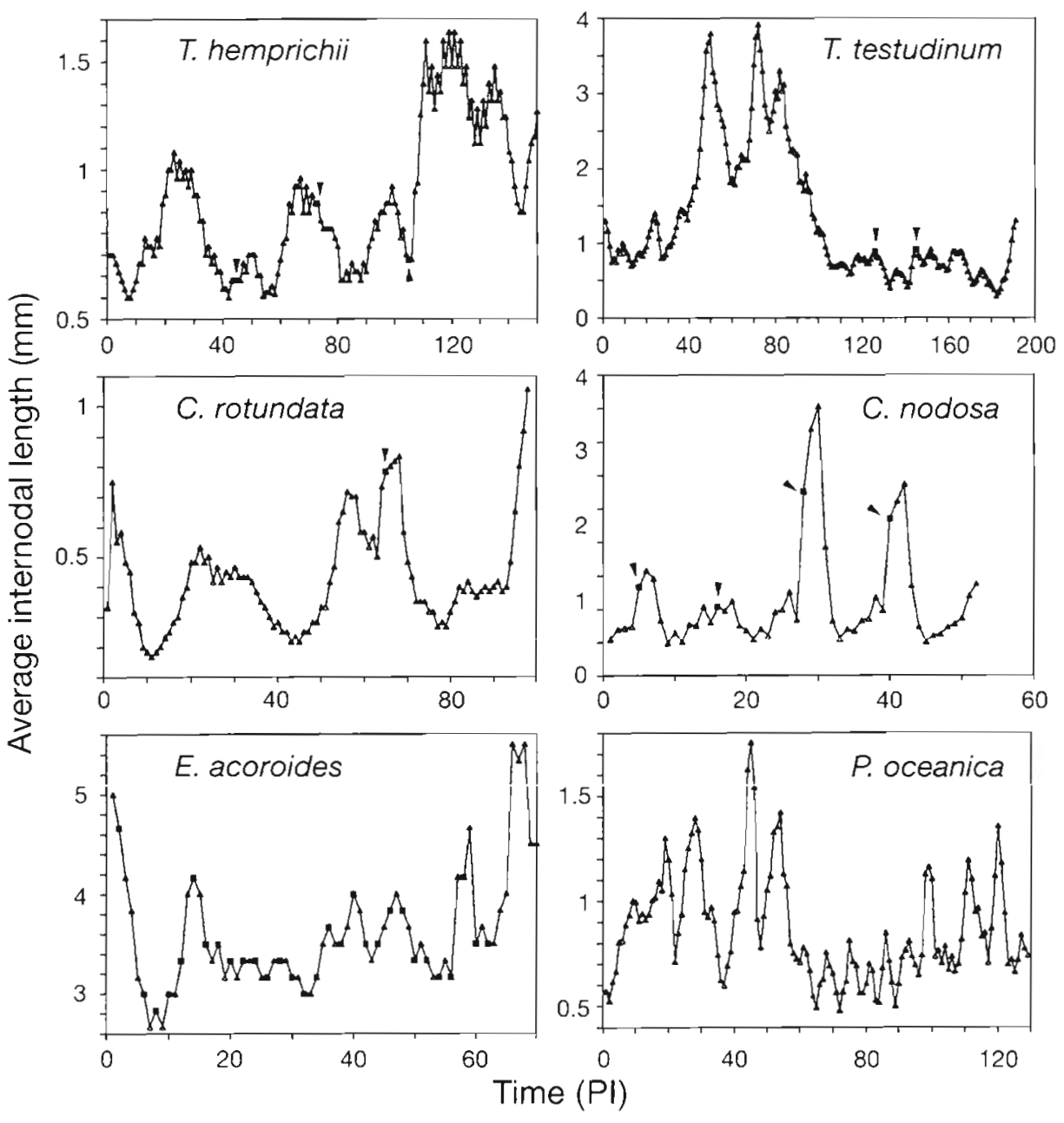

Fig. 3. Time series of vertical internodal length for different seagrasses sampled in the South China Sea, the Philippines (Thalassia hemprichii, Cymodocea rotundata and Enhalus

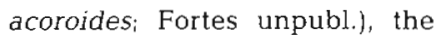
Mexican Caribbean (Thalassia testudinum; Gallegos unpubl.), and the Spanish Mediterranean (Posidonia oceanica and Cymodocea nodosa; Duarte unpubl.). The time series show annual cycles in vertical growth which can be used to infer the number of internodes $(=$ number of leaves) produced per shoot per year. Arrowheads indicate the position of successive flowering events along the shoot. PI: plastochrone intervals ficiently long-lived to be used for estimation of mean annual PI, the long rhizome pieces required may be difficult to retrieve.

We recently described the presence of seasonal patterns imprinted in the sequence of vertical internodal length of Thalassia testudinum shoots (Gallegos et al. 1992, Marbá et al. 1994a), which are easy to sample in comparison with horizontal rhizomes. This finding moved us to examine the sequence of internodal lengths of shoots of many other seagrasses, which consistently revealed similar seasonal signals (Fig. 3). These findings have a precedent in the study of tropical trees, for annual periodicity in internodal length has been described for other plants, such as mangroves (Duke \& Pinzón 1992).

Vertical rhizome growth also responds strongly to changes in sediment dynamics (e.g. Patriquin 1973, Boudouresque et al. 1984, Gallegos et al. 1993, Marbá et al. 1994a, b), which may disturb the annual signal in time series of vertical internodal length. Identification of annual cycles in internodal length in these cases requires that short-term and interannual variability be filtered out to highlight the seasonal signal. This can be achieved by applying a high- and low-frequency (e.g. running averages of ca 30 and ca $150 \%$ of the expected number of internodes contained in a cycle, respectively) filter to the raw data, which yields clearer signal at the seasonal scale (Fig. 4).

The considerable seasonality of rhizome growth in some seagrasses implies that the rate of production of new short shoots, which appear at regular intervals along the rhizomes, should be similarly seasonal. This conclusion is supported by many reports of seagrass seasonality which demonstrate shoot recruitment (i.e. density increase) to occur mostly in spring (e.g. Cymodocea nodosa, Terrados \& Ros 1992; Zostera marina, Sand-Jensen 1975; Heterozostera tasmanica, Bulthuis \& Woelkerling 1981). Hence, shoots appear in cohorts, rather than continuously throughout the year. This is reflected in the presence of distinct modes in frequency distributions of shoot age, given a sufficiently large (i.e. ca 1000) sample size (e.g. 

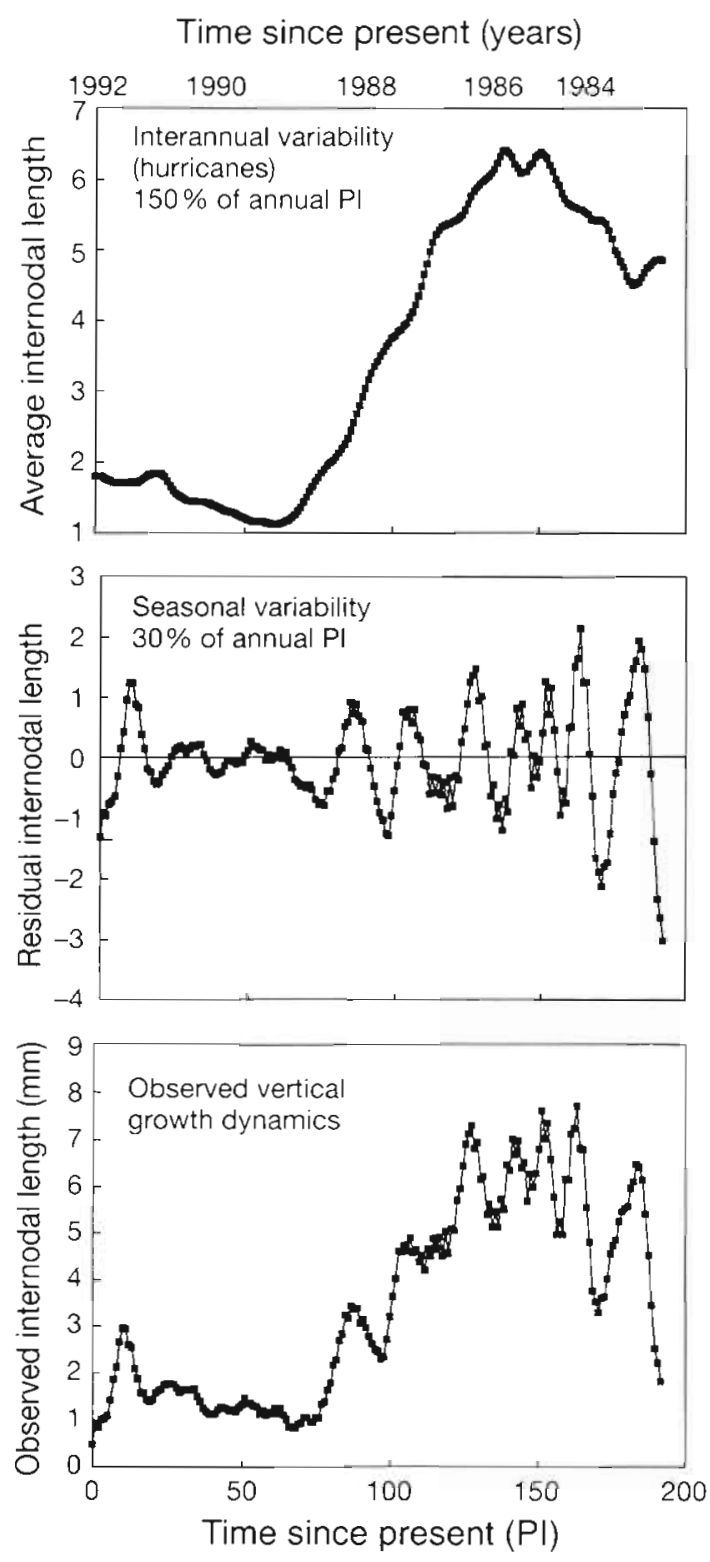

Fig. 4. Thalassia testudinum. Separation of the time series of vertical internodal length of samples from the Mexicar Caribbean (Gallegos unpubl.) into a long-term (interannual) and a seasonal component. The long-term component was obtained applying a filter (i.e. running average) equal to $150 \%$ of the number of internodes produced annually (17). and the seasonal component was obtained by subtracting the long-term component from the time series, which was then filtered for short-term variability (i.e. running average of 5 internodes or about $30 \%$ of the annual number of leaves produced per year). PI: plastochrone intervals

Cymodocea nodosa, Duarte \& Sand-Jensen 1990b; Fig. 5). The presence of these cohorts allows the calculation of the number of leaves produced per shoot per year as the mean age difference between cohort modes (Fig. 5).

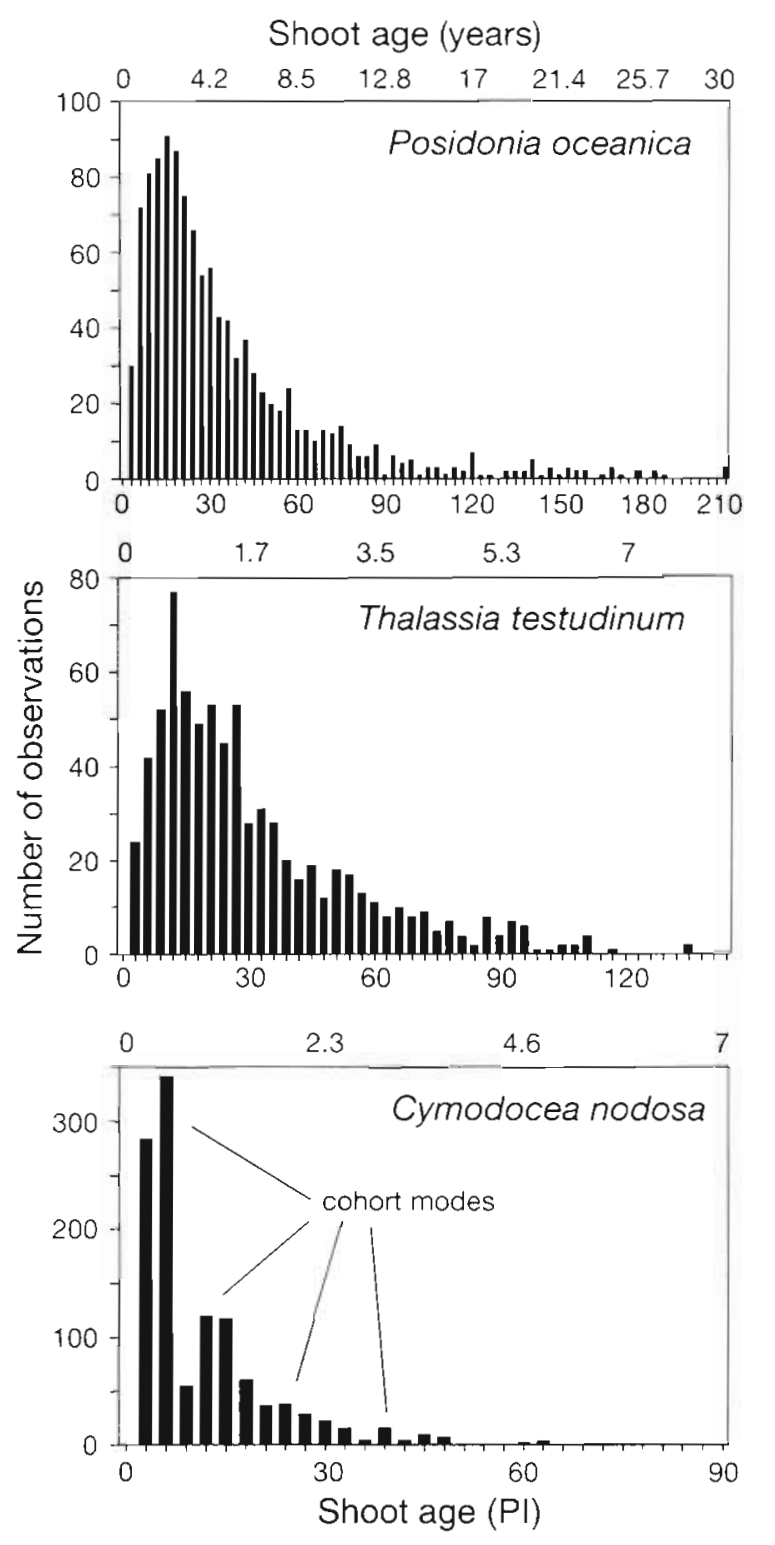

Fig. 5. Age frequency distribution [in plastochrone intervals (PI) and years! of living short shoots of different seagrasses sampled in the Spanish Mediterranean (Posidonia oceanica and Cymodocea nodosa; Duarte unpubl.) and the Mexican

Caribbean (Thalassia testudinum; Gallegos et al. 1993)

The annual mean PI can also be identified from flowering marks in species with a single flowering period per year (e.g. Cymodocea sp., Thalassia sp.). This is possible when flowering produces an identifiable scar on the shoot, whether scars left by the flower peduncle (e.g. the genus Thalassia, Cox \& Tomlinson 1988, Gallegos et al. 1992; the genus Cymodocea, Marbá unpubl.; Fig. 3) or other marks, such as the peculiar flower stalks of Posidonia oceanica (Pergent et al. 1989). Even though flower peduncles may not be formed in a synchronous manner over a short time 
Time after flowering (years)

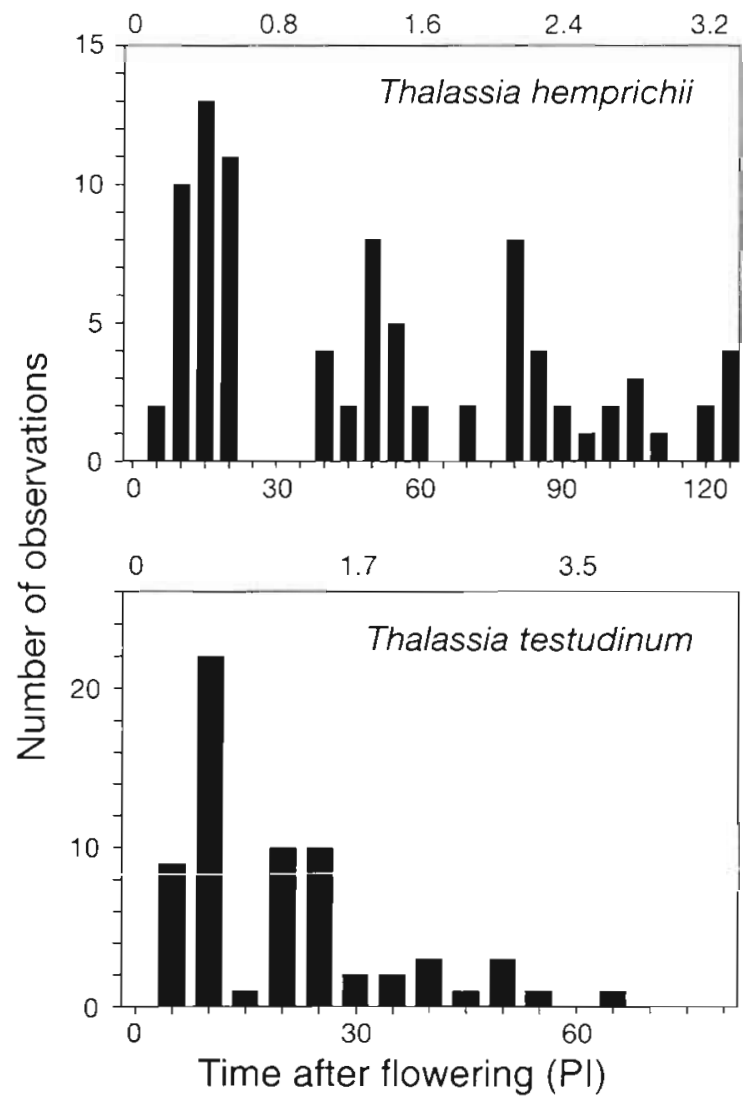

Fig. 6. Distribution of time elapsed [as plastochrone intervals (PI) units and years] since different short shoots flowered in populations sampled in the Mexican Caribbean (Thalassia testudinum; Gallegos et al. 1992) and the South China Sea, the Philippines (Thalassia hemprichij; Fortes unpubl.)

period (cf. Durako \& Moffler 1987), the distribution of time elapsed since flowering (as PI) shows distinct modes identifying the period of peak flowering (e.g. fall for $P$. oceanica, March-May for $T$. testudinum in the Mexican Caribbean; and May-June for C. nodosa in the Mediterranean) in successive years (Fig. 6). The time difference between these flowering modes corresponds to 1 yr or multiples of this time (Fig. 6), thereby allowing the estimation of the number of plastochrone intervals in $1 \mathrm{yr}$ as the minimum common multiple of these modes. Estimates based on the identification of flowering marks show good agreement with independent estimates (e.g. Gallegos et al. 1992), but may overestimate the PI for species which shoots reduce or stop leaf production during flowering (M. J. Durako pers. comm.). Because of the low fraction of shoots flowering each year (about 10\% on average for different seagrass species; Gallegos et al. 1992) many shoots need be collected to ensure adequate estimation of plastochrone intervals in this way.
Reconstruction of the plastochrone interval using age determinations is subject to different sources of uncertainty. It is, therefore, recommended that several of these methods be used simultaneously to crossvalidate the estimates obtained. Available results, however, demonstrate that the estimates of annual mean leaf production per shoot obtained using reconstruction techniques are strongly correlated to the observed (using marking techniques) annual leaf production (no. of leaves shoot ${ }^{-1} \mathrm{yr}^{-1}$ ),

Observed $=2.5( \pm 0.75)+0.85( \pm 0.06)$ Reconstructed $\left(\mathrm{R}^{2}=0.96, \mathrm{p}<0.0001\right)$

although there is a weak tendency for reconstructed values to be somewhat lower than those derived from marking techniques for species producing a small number of leaves per shoot annually (Fig. 7). Annual mean leaf production per shoot estimated using reconstruction techniques was not significantly different from estimates obtained using marking techniques (mean difference between observed and reconstructed $0.22 \pm 0.54, p=0.69 ;$ Fig. 7 ), thereby demonstrating the potential and validity of reconstruction techniques.

\section{Reconstructing seagrass dynamics: the tool box}

\section{Seagrass growth}

Reconstruction techniques allow calculation of the rate of production of different seagrass modules. This information allows the application of demographic growth analysis, which yields growth estimates remarkably close to those obtained using traditional growth analysis based on mass produced (e.g. SandJensen 1975, McGraw \& Garbutt 1990a, b). Hence, the set of reconstruction techniques described here hold great potential as alternative methods to estimate seagrass production (Patriquin 1973, Pergent \& PergentMartini 1990, Gallegos et al. 1993).

The descriptor of seagrass growth which can be most readily obtained using reconstruction techniques is the average number of leaves produced annually per shoot. All the reconstruction methods to estimate the mean annual PI described above enable the calculation of the number of leaves produced per shoot (i.e. $365 / P I$ ). This can be used as a surrogate of seagrass growth, therefore enabling one to examine interannual variability in seagrass growth. Using this technique Pergent (1990) identified a 3 to 6 yr cycle and an 11 yr cycle in the growth of Posidonia oceanica; Marbá et al. (1994a) described increased growth of Thalassia testudinum buried $<70 \mathrm{~cm}$ by sand by the passage of Hurricane Gilbert in the Mexican Caribbean; and 


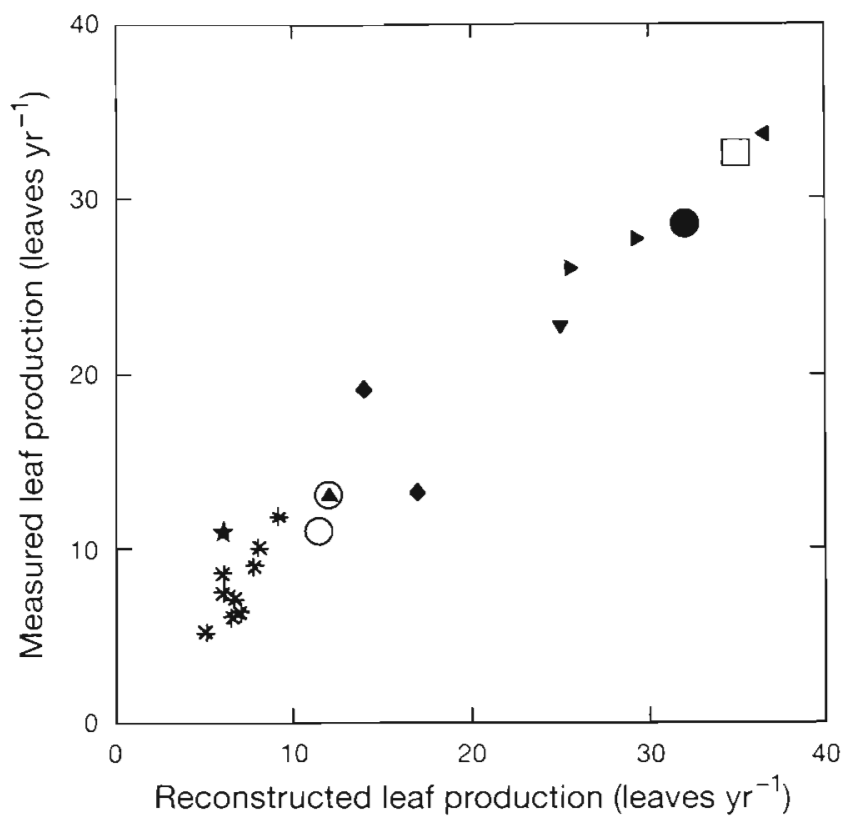

Fig. 7. Relationship between the number of leaves produced annually, estimated using marking and reconstruction techniques, for different seagrass species sampled in the Spanish Mediterranean ( * Posidonia oceanica, Zostera marina, $\nabla$ Zostera noltii, O Cymodocea nodosa; Marbá unpubl.), the Caribbean Sea off Yucatan Peninsula, Mexico ( Thalassia testudinum, $\star$ Syringodium filiforme; Gallegos unpubl.) and the South China Sea, the Philippines ( Thalassia hemprichii, Cymodocea rotundata, $\square$ Cymodocea serrulata, Enhalus acoroides; Fortes unpubl.)

Fortes (unpubl.) identified a correlation between growth of Enhalus acoroides and interannual weather patterns. This technique may prove particularly useful to study the consequences of perturbations to seagrass populations for which no background data exist. In addition, estimates of the average number of leaves annually produced per shoot allow calculation of the average annual leaf turnover and leaf production. Annual leaf turnover can be calculated as the ratio between the number of leaves produced per year and the average number of standing leaves per shoot, and annual shoot leaf production as the product of the number of leaves annually produced per shoot and the mean weight of fully developed leaves.

More important, these techniques also enable reconstruction of rhizome growth (Patriquin 1973, 1975, Duarte \& Sand-Jensen 1990a, Pergent \& PergentMartini 1990, Terrados \& Ros 1992, Gallegos et al. 1993). Patriquin (1973) noted that the growth rate of the rhizome may be obtained by dividing the length of the rhizome between 2 shoots by the difference in the ages of the 2 shoots. This simple ratio is, however, appropriate only for species producing new shoots along the rhizome at time intervals longer than 1 leaf PI, so that con-

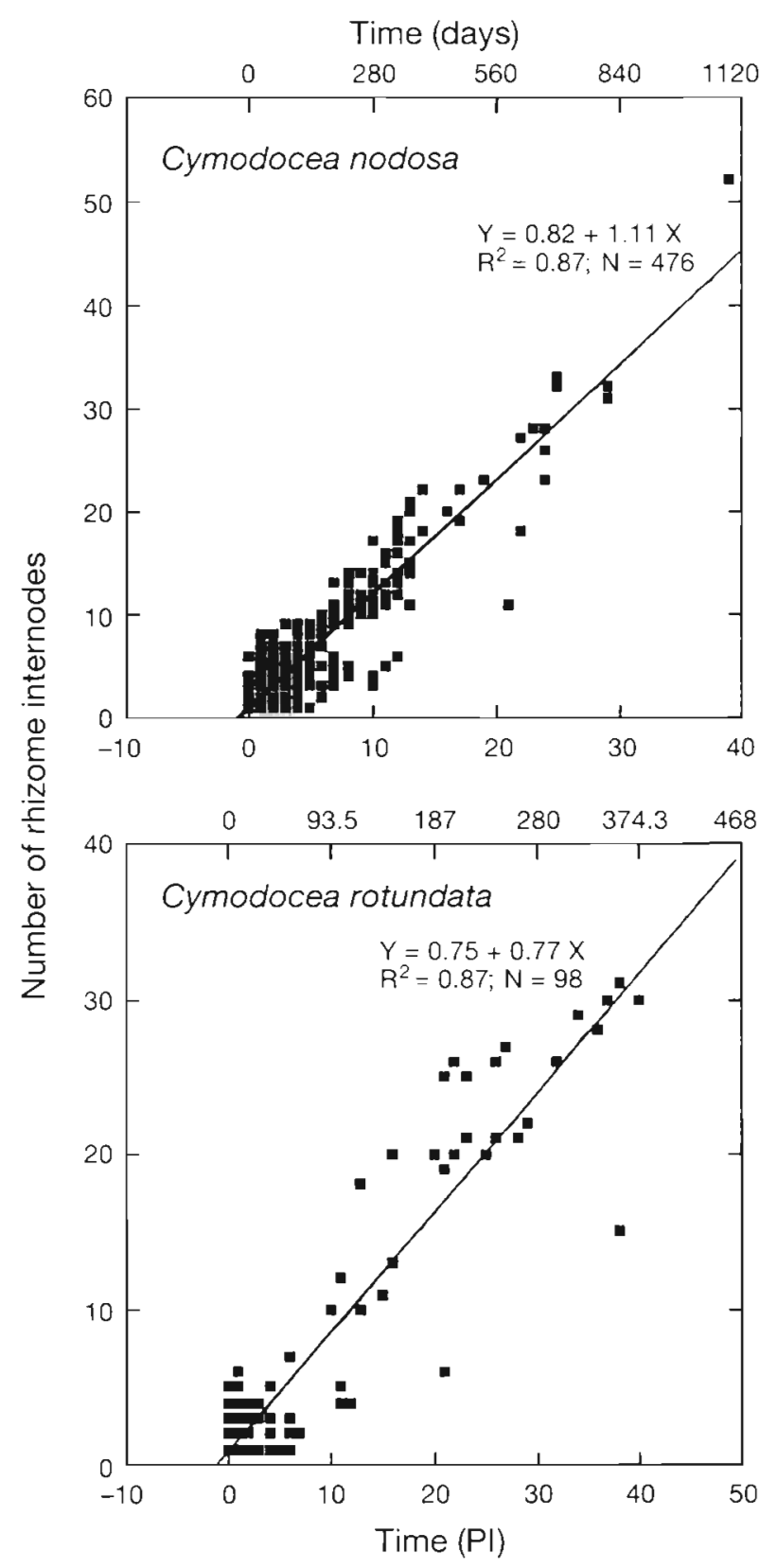

Fig. 8. Relationship between the number of rhizome internodes in between shoots connected along rhizome chains and sampled in the Spanish Mediterranean (Cymodocea nodosa; Duarte unpubl.) and the South China Sea, the Philippines (Cymodocea rotundata; Fortes unpubl.) and their age differences. The slopes of these relationships indicate the average number of internodes produced per plastochrone interval (PI) and allow, in combination with the average

internodal length, calculation of rhizome elongation rate

secutive shoots differ in age by $>1$ leaf PI. An alternative, more accurate, way to calculate rhizome elongation rate is to regress the number of internodes in between 2 shoots connected along a rhizome piece against their age difference (Fig. 8). The regression slope represents 


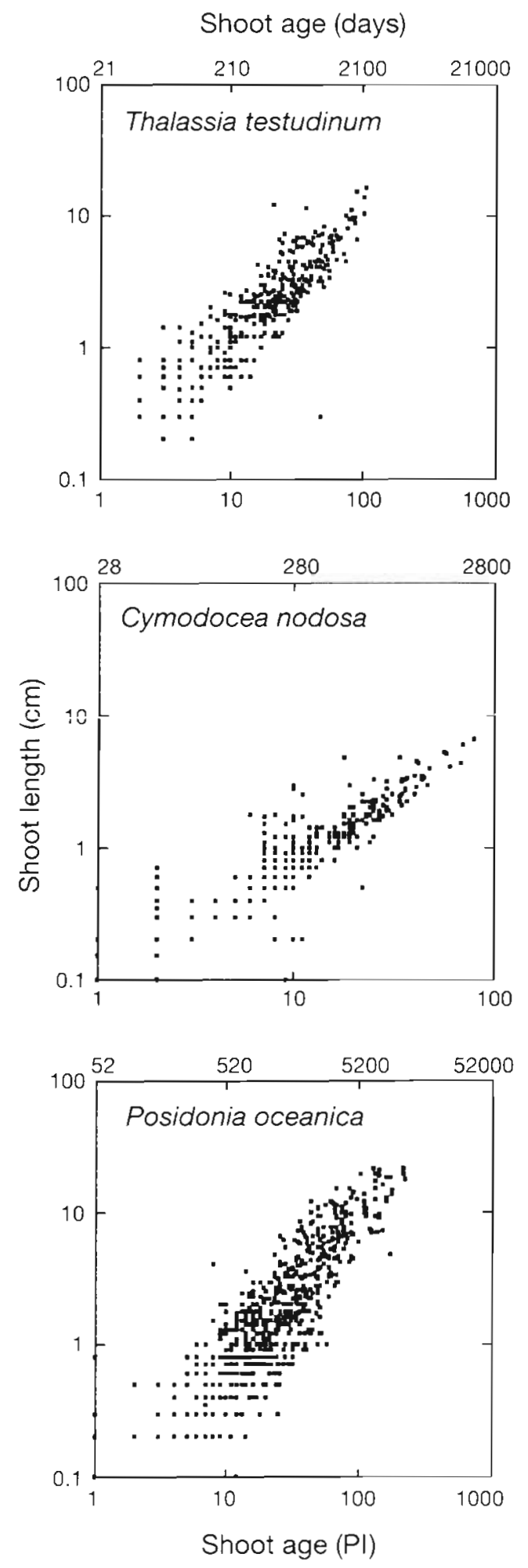

Fig. 9. Relationship between the length of vertical shoots of different seagrass species sampled in the Mexican Caribbean (Thalassia testudinum; Marbà et al. 1994a) and the Spanish Mediterranean (Posidonia oceanica and Cymodocea nodosa; Marbà unpubl.), and their age the average number of rhizome internodes produced per PI (rhizome PI; cf. Patriquin 1973, Duarte 1991, Gallegos et al. 1993), which can be translated into rhizome elongation rate by multiplying this slope by the average length of a rhizome internode.

The growth of vertical rhizomes (i.e. short shoots) allows seagrasses to survive sediment accretion (Patriquin 1973, Boudouresque et al. 1984, Eleuterius 1987, Marbà et al. 1994a, b) and contribute to rhizome production (Gallegos et al. 1993). Vertical growth can also be easily calculated by regressing the length of short shoots (from their insertion on the horizontal rhizome to the apical meristem) against shoot age, with the slope representing the vertical elongation rate (Fig. 9).

Knowledge of rhizome growth rates enables one, in turn, to calculate areal rhizome production as the sum of the production of horizontal and vertical rhizomes. Horizontal rhizome production can be estimated as the product of the elongation rate, the number of growing rhizome apices per unit area, and the specific weight of rhizome material (Patriquin 1973). The areal production of vertical rhizonles can be estimated as the product of their elongation rate, shoot density, and the specific weight of rhizome material (Gallegos et al. 1993). Seagrass roots often appear as a bundle at the insertion of shoots on the rhizomes, and root biomass is linearly scaled to shoot density (Francou \& Semroud 1992). Because the number of rhizome internodes in between consecutive shoots is relatively constant and easy to determine (e.g. Patriquin 1973), root production can be calculated as the product of the root weight per unit rhizome biomass and the production of horizontal rhizomes. The production of roots in the vertical shoots can also be estimated by regressing the number or biomass of roots formed against shoot age (Duarte unpubl.).

Reconstruction techniques were first used to measure leaf production of Zostera marina by Petersen (1913), and both leaf and rhizome production of Thalassia testudinum by Patriquin (1973). Subsequently, they have been used to measure the production of T. testudinum in the Mexican Caribbean (Gallegos et al. 1993); to reconstruct the leaf production of the Mediterranean seagrass Posidonia oceanica (Pergent \& Pergent-Martini 1990); and the rhizome elongation and production rates of Cymodocea nodosa (Perez 1989, Duarte \& Sand-Jensen 1990a, b, Terrados \& Ros 1992). These studies all demonstrate that reconstruction techniques provide reliable estimates of seagrass production, and are powerful tools to expand our knowledge of seagrass growth to remote areas where the repetitive visits required by standard techniques are difficult. They also make large-scale surveys of seagrass growth with limited resources possible. 
Hence, increased use of reconstruction techniques should help expand and balance the geographic distribution of our knowledge of seagrass ecology.

\section{Seagrass population dynamics}

Seagrasses are modular plants with a continuous production, and loss, of modules (Tomlinson 1974). This continuous turnover is most evident for leaves, and represents the foundation of marking techniques to estimate seagrass production (Zieman 1974). However, seagrass shoots are also subject to a continuous turnover which is reflected by the age structure of the shoots (Duarte \& Sand-Jensen 1990b, Gallegos et al. 1992, 1993, Perez et al. 1994).

Seagrass shoots have an age structure often characterised by few very young shoots with 1 to 2 leaves, many young $(<1$ yr old) shoots, and exponentially declining numbers with increasing shoot age (Fig. 5). The relative scarcity of very young shoots is likely accounted for by Patriquin's (1973) observation that the first leaves on vertical shoots are produced much faster than subsequent leaves. The exponential decline in shoot abundance with increasing age results from shoot mortality and allows estimation of exponential shoot mortality rates $\left(M, \ln\right.$ units time $\left.{ }^{-1}\right)$ as the negative slope of the exponential equation,

$$
N_{i}=N_{0} \mathrm{e}^{-M i}
$$

where $N_{0}=$ number of shoots with age equal to the mode; and $N_{t}=$ number of shoots older than modal shoots by time $t$. This calculation assumes constant annual shoot mortality and recruitment rates, and may, therefore, involve error when this assumption is not fulfilled (Gallegos et al. 1993). Annual shoot recruitment rates $\left(R_{\text {gross }}\right.$ In units $\left.\mathrm{yr}^{-1}\right)$ can also be calculated from the total number of shoots $\left(\sum_{t=0}^{\infty} N_{t}\right)$ and the number of shoots older than a year $\left(\sum_{t=1}^{\infty} N_{t}\right)$ in the shoot population (Duarte \& Sand-Jensen 1990b, Gallegos et al. 1993) as

$$
R_{\mathrm{gross}}=\ln \sum_{t=0}^{\infty} N_{t}-\ln \sum_{t=1}^{\infty} N_{t}
$$

Knowledge of gross recruitment and mortality rate helps forecast seagrass population dynamics, which depends on net annual shoot recruitment $\left(R_{\text {net }}\right)$, since

$$
R_{\text {net }}=R_{\text {gross }}-M
$$

Positive net shoot recruitment rates predict increasing seagrass density, whereas populations with negative net shoot recruitment rates are in decline (e.g. Duarte \& Sand-Jensen 1990b).

Seagrass rhizomes often decompose slowly (Harrison 1989), such that vertical shoots remain attached to the rhizome for some time after shoot death. Shoot death generally involves the death of the leafproducing meristem in the shoot apex, which appears to be preceded by a narrowing of the meristem and production of very thin leaves (Gallegos et al. 1993, Duarte pers. obs.). Hence dead shoots often can be differentiated from broken shoots, because they have a rounded, instead of truncated, apex (e.g. genera Thalassia, Cymodocea, Halodule, Syringodium, Posidonia; Gallegos et al. 1993, 1994, Duarte pers. obs., Fortes pers. obs.). The presence of many dead shoots in seagrass populations is a consequence of their continuous turnover and is a convenient tool to reconstruct seagrass growth (Gallegos et al. 1993). The median age of dead shoots represents their median life expectancy and is, therefore, a useful indicator of shoot turnover time (Gallegos et al. 1993). Indeed, the life expectancy of shoots indicates the median time for all shoots to die which should be equivalent, if the seagrass meadow approaches steady state, to the turnover time of shoots. Because the shoots appear at regular intervals along the rhizomes, the shoot turnover time calculated in this way should be of the same order as the rhizome turnover time (Gallegos et al. 1993).

The frequency distribution of shoot age-at-death is often fitted much better by an exponential loss function (Fig. 10) than that of living shoots (Fig. 5; Gallegos et al. 1993). The reason for this is that the distribution of ageat-death combines all shoots dying at a particular age regardless of which year they were produced, hence averaging out interannual variability in recruitment and mortality (Gallegos et al. 1993). Mortality estimates derived from the distribution of age-at-death are, therefore, more robust than those obtained from the distribution of living shoots (Gallegos et al. 1993), but represent average estimates along the life span of the shoots.

Mortality and recruitment estimates are useful to evaluate the status of seagrass meadows and to forecast their development. Seagrass populations at near steady state should show a balance between shoot mortality and recruitment. Deviations towards recruitment rates higher than mortality rates and vice versa are indicative of expanding and declining populations, respectively (Duarte \& Sand-Jensen 1990b). In addition, quantification of seagrass shoot life span is a convenient estimate of what the average life span of the rhizome material might be.

\section{Seagrass colonisation and reproduction}

Seagrasses often experience mass mortality and substantial reductions in the extension of their meadows (Kemp et al. 1983, Cambridge \& McComb 1984), which has far-reaching consequences in the ecosystem, such 

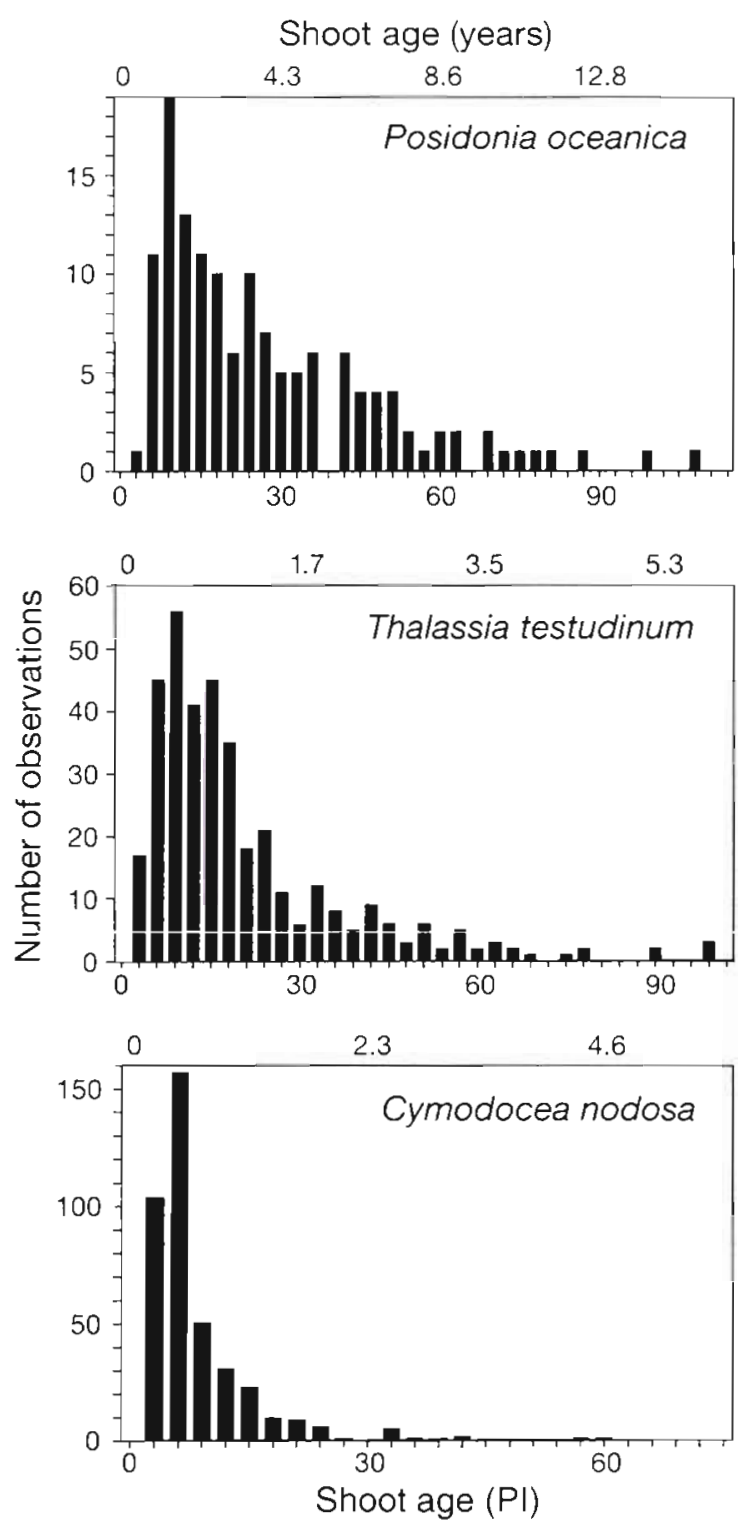

Fig. 10. Frequency distribution of age-at-death of short shoots of different seagrasses sampled in the Spanish Mediterranean, (Posidonia oceanica and Cymodocea nodosa; Duarte unpubl.) and the Mexican Caribbean (Thalassia testudinum; Gallegos et al. 1993) showing the exponential decline in shoot number with age that allows calculation of mortality rate

as sediment erosion and loss of associated biota (Christiansen et al. 1981). Forecasting seagrass colonisation is, therefore, important to predict ecosystem recovery. There is, however, a remarkable paucity of quantitative data on the rate of seagrass recovery which prevents the development of models to forecast this process.

Reconstruction techniques are valuable tools to measure patch formation and patch expansion rates, the main processes involved in seagrass recovery
(Duarte \& Sand-Jensen 1990a). Seagrass patches often develop by seed dispersal followed by seedling establishment and expansion of the formed patch by rhizome growth (Duarte \& Sand-Jensen 1990a). Reconstruction techniques allow calculation of seagrass flowering intensity, which sets an upper limit to the seed production possible. Flowering intensity can often be estimated because identification of flower scars (e.g. genera Thalassia, Cymodocea, Enhalus; Durako \& Moffler 1987, Cox \& Tomlinson 1988, Gallegos et al. 1993, 1994, Duarte pers. obs., Fortes pers. obs.) or flower peduncles (e.g. Pergent \& PergentMartini 1990) allows calculation of both the time elapsed since the flower was produced (i.e. number of leaves and leaf scars produced since appearance of the flower scar), and the age at which the shoot flowered (i.e. number of leaf scars from the shoot insertion point to the flower scar; Cox \& Tomlinson 1988, Gallegos et al. 1992). Quantitative sampling of seagrass shoots yields, therefore, considerable insight into the reproductive biology of seagrasses, such as calculation of past flower intensity (Pergent et al. 1989, Gallegos et al. 1992) and examination of the age-dependence of shoot flowering ( Gallegos et al. 1992).

Flowering intensity is, however, of limited use to assess the potential formation of new patches, which depends on seed production, germination, and the survival and subsequent growth of the seedlings. Yet, seedling production and survivorship can also be estimated using reconstruction techniques (Duarte \& Sand-Jensen 1990a). Seagrass seedlings can be easily identified because they often lack rhizome connections to other shoots and because they often retain remains of the seed coat at their base. Seedling age, as estimated from the number of leaves and leaf scars on the short shoot, represents the time elapsed since germination. Estimating net seedling production from quantitative evaluation of seedling abundance is, therefore, straightforward (Duarte \& Sand-Jensen 1990a). Moreover, the age distribution of seedlings often presents a sharp exponential decline which allows estimation of seedling mortality rates (see above). Seedling survival, however, is not sufficient to ensure formation of a new seagrass patch, for seedlings may survive without producing horizontal rhizomes and new shoots (Duarte \& Sand-Jensen 1990a). The proportion of seedlings producing horizontal rhizomes, as well as the timing of this event, can also be evaluated using reconstruction techniques (Duarte \& Sand-Jensen 1990a) which allow, therefore, quantification of different aspects of seedling growth and the establishment of new patches.

Seagrass patches expand through rhizome growth leading to space occupation (Bell \& Tomlinson 1980 , Duarte \& Sand-Jensen 1990a). The maximal rate of patch expansion is set by the maximal rate of horizontal 
rhizome elongation, but this capacity is not necessarily realised in natural seagrass patches. The monopodial growth of the rhizomes of many seagrass species (Tomlinson 1974) implies that patches grow centrifugally through long rhizomes (runners), which branch subsequently to occupy the space and increase local density. The rate of patch growth and internal biomass development can also be quantified using reconstruction techniques (Duarte \& Sand-Jensen 1990a, b). The location within a seagrass patch where the oldest shoots are encountered represents the site of patch initiation, whenever these are younger than the maximum life expectancy of the species examined (Patriquin 1975, Duarte \& Sand-Jensen 1990a). Similarly, the gradient of maximal shoot age along the main axis of seagrass patches provide estimates of the time course of patch growth (Patriquin 1975, Duarte \& Sand-Jensen 1990a). The horizontal gradient of maximal age across the patch axes represents, therefore, the patch expansion rate, calculated as the slope of the regression equation relating distance from the patch margin to maximal shoot age (Duarte \& Sand-Jensen 1990a).

\section{Seagrass as tracers of sediment transport and chemistry}

Seagrasses may inhabit highly dynamic substrates and adapt to sediment accretion, and burial, by the ability to grow vertically (see above) and raise the rhizome meristems to the new sediment level. Seagrasses relocate their meristems closer to the sediment surface after burial by speeding up the vertical growth of their shoots and develop new layers of horizontal rhizomes from meristems in vertical rhizomes (e.g. Thalassia testudinum, Tomlinson 1974; Cymodocea nodosa, Cayé \& Meinesz 1985). Patriquin (1973) first noted that the vertical growth of $T$. testudinum shoots differed considerably among populations and suggested that this could be used to estimate sedimentation rates. His suggestion that seagrasses hold potential as tracers of sediment migration was developed further in an examination of the extent and 'migration' of erosional scarps ('blowouts') along $T$. testudinum meadows using age determinations (Patriquin 1975). The close coupling between sediment accretion rates and seagrass vertical growth has been demonstrated since for other turtlegrass meadows off the Yucatan Peninsula (Marbá et al. 1994a), as well as for the Mediterranean species Posidonia oceanica (Boudouresque et al. 1984) and $C$ nodosa (Marbá et al. 1994b).

The coupling between seagrass vertical growth and sediment accretion is so close that abrupt changes in the length of the vertical internodes can be used to trace the timing of burial events (Marbá et al. 1994b).
This allowed the estimation of the migration velocity of large-scale subaqueous bedforms over Cymodocea nodosa patches in a Mediterranean bay by estimating the time interval between passage of successive dunes over a seagrass patch and following the time course of transit of individual subaqueous dunes over seagrass patches (Marbá et al. 1994b).

In addition to their use as tracers of sediment accretion and erosion, seagrasses are also useful indicators of changes in sediment chemistry. The rhizomes of the long-living Mediterranean seagrass Posidonia oceanica preserved a record of atmospheric caesium fallout, which closely matched that of known atmospheric loading (Pergent et al. 1983, Calmet et al. 1988). This capacity is most useful in long-lived seagrasses, whose tissues remain for decades (e.g. P. oceanica, Enhalus acoroides, Thalassodendron ciliatum). The use of seagrasses as tracers of past chemical environments is probably restricted to compounds not greatly involved in metabolism and rapidly translocated within the plants. Despite the obvious relevance, however, this potential use of seagrasses has not been explored further.

\section{CONCLUSIONS}

The ability to determine the age of organisms has proven most useful in elucidating their ecology and population dynamics, as exemplified by the power of tree rings to reconstruct past climates, and the power of growth rings in otoliths and mussel shells to examine organismal growth rate and its interannual variability in relation to known perturbations. Similarly, we demonstrate here that the ability to determine the age of seagrass modules is a strong instrumental tool to reconstruct key components of seagrass dynamics (growth, population dynamics, reproductive effort and recovery rates), as well as to reconstruct processes in their sediment environment.

The use of this set of techniques is restricted to studies focused at annual, or longer, time scales. Accordingly, the approach described here is most powerful when used to examine long-lived seagrass species. Yet, the use of techniques based on age determinations was first demonstrated for Zostera marina (Petersen 1913), with rhizome chains lasting only 1 to $2 \mathrm{yr}$, and we have successfully applied these techniques to study short-lived species (Halodule wrightii and Syringodium filiforme; Gallegos et al. 1994). We contend, therefore, that techniques based on age determinations should be applicable to most seagrass genera. Hence, reconstruction techniques increase the possibility to improve and increase the balance of our knowledge of the role of seagrasses in the planet's coastal zones. 
Acknowledgements. This research was partially funded by project CI1 ${ }^{\circ}$-CT91-0952 from the Commission of the European Communities. We thank Gustavo Carreras for the artwork and Mike Durako for useful comments.

\section{LITERATURE CITED}

Barber, B. J., Beherens, P. J. (1985). Effects of elevated temperature on seasonal in situ leaf productivity of Thalassia testudinum Banks ex König and Syringodium filiforme Kutzing. Aquat. Bot. 22: 61-69

Bell, A. D., Tomlinson, P. B. (1980). Adaptative architecture in rhizomatous plants. Bot. J. Linnean Soc. 80: 125-160

Boudouresque, C. F., Jeudy de Grissac, A., Meinesz, A. (1984). Relations entre le sédimentation et l'allongement des rhizomes orthotropes de Posidonia oceanica dans la Baie d'Elbu (Corse). In: Boudouresque, C. F., Jeudy de Grissac, A., Olivier, J. (eds.) International workshop on Posidonia beds. GIS Posidonia, Marseilles, p. 185-191

Brouns, J. J. W. M. (1985a). The plastochrone interval method for the study of the productivity of seagrasses; possibilities and limitations. Aquat. Bol. 21: 71-88

Brouns, J. J. W. M. (1985b). A comparison of the annual production and biomass in three monospecific stands of the seagrass Thalassia hemprichii (Ehrenb.) Aschers. Aquat. Bot. 23: $149-175$

Brouns, J. J. W. M. (1987). Growth patierus of some incioWest-Pacific seagrasses. Aquat. Bot. 28: 39-61

Bulthuis, D. A., Woelkerling, W. J. (1981). Effects of in situ nitrogen and phosphorus enrichment of the sediments on the seagrass Heterozostera tasmanica (Martens ex Aschers.) den Hartog in Western Port, Victoria, Australia. J. exp. mar. Biol. Ecol. 53: 193-207

Calmet, D., Boudouresque, C. F., Meinesz, A. (1988). Memorization of nuclear atmospheric tests by rhizomes and scales of the Mediterranean seagrass Posidonia oceanica (Linnaeus) Delile. Aquat. Bot. 30: 279-294

Cambridge, M. L., McComb, A. J. (1984). The loss of seagrasses in Cockburn Sound, Western Australia. I. The time course and magnitude of seagrass decline in relation to industrial development. Aquat. Bot. 20: 229-243

Cayé, G., Meinesz, A. (1985). Observations on the vegetative development, flowering and seedling of Cymodocea nodosa (Ucria) Ascherson on the Mediterranean coasts of France. Mar. Ecol. Prog. Ser. 22: 277-289

Christiansen, C., Christoffersen, H., Dalsgaard, J., Nornberg, R. (1981). Coastal and nearshore changes correlated with die-back in eelgrass (Zostera marina L.). Sedimentary Geol. 28: 163-173

Cox, P. A., Tomlinson, P. B. (1988). Pollination ecology of seagrass, Thalassia testudinum (Hydrocharitaceae), in St. Croix. Am. J. Bot. 75: 958-965

den Hartog, C. (1970). The seagrasses of the world. North Holland Publ., Amsterdam

Duarte, C. M. (1991). Allometric scaling of seagrass form and productivity. Mar. Ecol. Prog. Ser. 77: 289-300

Duarte, C. M., Sand-Jensen, K. (1990a). Seagrass colonization: patch formation and patch growth in Cymodocea nodosa. Mar. Ecol. Prog. Ser. 65: 183-191

Duarte, C. M., Sand-Jensen, K. (1990b). Seagrass colonization: biomass development and shoot demography in Cymodocea nodosa patches. Mar. Ecol. Prog. Ser. 67: $97-103$

Duke, N. C., Pinzón, M. (1992). Aging Rhizophora seedlings from leaf scar nodes: a technique for studying recruitment and growth in mangrove forests. Biotropica 24: 173-186
Durako, M. J., Moffler, M. D. (1987). Factors affecting the reproductive ecology of Thalassia testudinum (Hydrocharitaceae). Aquat. Bot. 27: 79-85

Eleuterius, L. N. (1987). Seagrass ecology along the coasts of Alabama, Louisiana, and Mississippi. In: Durako, M. J., Phillips, R. C., Lewis, R. R. III (eds.) Proc. symp. subtropical-tropical seagrasses in the southeastern United States. Fla mar. Res. Publ. 42: 11-20

Erickson, R. O., Michelini, F. J. (1957). The plastochron index. Am. J. Bot. 44: 297-305

Francou, P., Semroud, R. (1992). Calculation of the root area index in Posidonia oceanica in the western Mediterranean. Aquat. Bot. 42: 281-286

Gallegos, M. E., Merino, M., Marbà, N., Duarte, C. M. (1992). Flowering of Thalassia testudinum in the Mexican Caribbean: age-dependence and interannual variability. Aquat. Bot. 43: 249-255

Gallegos, M. E., Merino, M., Marbà, N., Duarte, C. M. (1993). Biomass and dynamics of Thalassia testudinum in the Mexican Caribbean: elucidating rhizome growth. Mar. Ecol. Prog. Ser. 95: 185-192

Gallegos, M. E., Merino, M., Rodriguez, A., Marbà, N., Duarte, C. M. (1994). Growth patterns and demography of pioneer Caribbean seagrasses (Halodule wrightii and Syringodium filiforme). Mar. Ecol. Prog. Ser. (in press)

Harrison, P. G. (1989) Detrital processing in seagrass systems: a review of factors affecting decay rates, remineralization and detritivory. Aquat. Bot. 23: 263-288

Hillman, K., Walker, D. I., Larkum, A. W. D., McComb, A. J. (1989). Productivity and nutrient limitation. In: Larkum, A. W. D., McComb, A. J., Shepherd, S. A. (eds.) Biology of seagrasses. A treatise on the biology of seagrasses with special reference to the Australian region. Elsevier, Amsterdam, p. 635-685

Kemp, W. M., Twilley, R. R., Stevenson, J. C., Boynton, W. R., Means, J. C. (1983). The decline of submerged vascular plants in upper Chesapeake Bay: summary of results concerning possible causes. Mar. Technol. Soc. J. 17: 78-89

Lamoreaux, R. J., Chaney, W. R., Brown, K. M. (1978). The plastochron index: a review after two decades of use. Am. J. Bot. 65: 586-593

Marbà, N., Cebrián, J., Enríquez, S., Duarte, C. M. (1994b). Migration of large scale subaqueous bedforms measured using seagrasses (Cymodocea nodosa) as tracers. Limnol. Oceanogr. 39: in press

Marbà, N., Gallegos, M. E., Merino, M., Duarte, C. M. (1994a). Vertical growth of Thalassia testudinum: seasonal and interannual variability. Aquat. Bot. 47: 1-12

McGraw, J B, Garbutt, J. (1990a). Demographic growth analysis. Ecology 7: 1199-2004

McGraw, J. B., Garbutt, J. (1990b). The analysis of plant growth in ecological evolutionary studies. Trends Ecol. Evol. 5: 251-254

Patriquin D. G. (1973). Estimation of growth rate, production and age of the marine angiosperm Thalassia testudinum König. Carib. J. Sci. 13: 111-123

Patriquin, D. G. (1975). 'Migration' of blowouts in seagrass beds at Barbados and Carriacou, West Indies, and its ecological and geological implications. Aquat. Bot. 1: 163-189

Perez, M. (1989). Fanerógamas marinas en sistemas estuáricos: producción, factores limitantes, y algunos aspectos del ciclo de nutrientes. Ph.D. thesis, Universidad de Barcelona

Perez, M., Duarte, C. M., Romero, J., Sand-Jensen, K., Alcoverro, T (1994). Growth plasticity in Cymodocea nodosa stands: the importance of nutrient supply. Aquat. Bot. 47: in press 
Perez, M., Romero, J., Duarte, C. M., Sand-Jensen, K. (1991). Phosphorus limitation of Cymodocea nodosa growth. Mar. Biol. 109: 129-133

Pergent, G. (1990). Lepidochronological analysis of the seagrass Posidonia oceanica (L.) Delile: a standardized approach. Aquat. Bot. 37: 38-54

Pergent, G., Ben Maiz, N., Boudouresque, C. F., Meinesz, A. (1989). The flowering of Posidonia oceanica over the past fifty years: a lepidochronological study. In: Boudouresque, C. F., Meinesz, A., Freal, E., Gravez, V. (eds.) Intern. Workshop on Posidonia Beds, Vol. 2. GIS Posidonia, Marseilles, p. 69-76

Pergent, G., Boudouresque, C. F., Crouzet, A. (1983). Variations cycliques dans les écailles des rhizomes orthotropes de Posidonia oceanica. Trav. sci. Parc nat. Pot-Cros, Fr. 9: $107-148$

Pergent, G., Pergent-Martini C. (1990). Some applications of lepidochronological analysis in the seagrass Posidonia oceanica. Botanica mar. 33: 299-310

Petersen, C. G. J. (1913). Om Baendeltangens (Zostera marina) Aarsproduktion i de danske Farvande. In: Jungersen, H. F. E., Warming, E. (eds.) Mindeskr. Japetus Steenstrups Fødsel, Vol. 9. G. E. C. Gad, Copenhagen, p. 1-20

Sand-Jensen, K. (1975). Biomass, net production and growth dynamics in an eelgrass (Zostera marina L.) population in Vellerup Vig, Denmark. Ophelia 14: 185-201

Sarukhán, J. (1978). Studies on the demography of tropical

This review was presented by G. W. Thayer (Senior Editorial Advisor), Beaufort, N. Carolina, USA trees. In: Tomlinson, P. B., Zimmermann, H. (eds.) Tropical trees as living systems. Cambridge University Press, Cambridge, p. 163-184

Short, F. T (1987). Effects of sediment nutrients on seagrasses: literature review and mesocosm experiment. Aquat. Bot. 27: 41-57,

Sokal, R. R., Rohlf, F. J. (1981). Biometry. The principles and practice of statistics in biological research. W. H. Freeman and Company, New York

Terrados, J., Ros, J. D. (1992). Growth and primary production of Cymodocea nodosa (Ucria) Ascherson in a Mediterranean coastal lagoon: the Mar Menor (SE Spain). Aquat. Bot. 43: 63-74

Tomlinson, P. B. (1974). Vegetative morphology and meristem dependence. The foundation of productivity in seagrasses. Aquaculture 4: 107-130

Tomlinson, P. B., Vargo, G. A. (1966). On the morphology and anatomy of turtle grass, Thalassia testudinum (Hydrocharitaceae). 1 Vegetative morphology. Bull. mar. Sci. 16: $748-761$

van Tussenbroek, B. (1993). Spatial and seasonal variability in biomass and leaf morphology of the manatee grass, Syringodium filiforme in a tropical coral reef lagoon, Mexico. Annls Inst. Cien. Mar Limnol. (in press)

Zieman, J. C. (1974). Methods for the study of the growth and production of the turtle grass, Thalassia testudinum König Aquaculture 4: 139-143

Manuscript first received: June 5, 1993

Revised version accepted: January 28, 1994 